\title{
Alternative media and normative theory: A case of Ferguson, Missouri
}

\author{
Mark Anthony Poepsel ${ }^{1}$
}

Southern Illinois University - Edwardsville, USA

\section{Chad Painter ${ }^{2}$}

University of Dayton, USA

\section{doi: $10.5937 /$ comman 11-9615}

Abstract: This paper, based on in-depth interviews with journalists at alternative and advocacy papers in St. Louis as well as interviews with live streaming protestors, a new breed of citizen journalist, applies six characteristics commonly associated with the alternative press to coverage of the protests and police crackdown in Ferguson, Missouri between August 9, 2014 and March 2015. Journalists from the alternative newspaper in St. Louis focused on progressive or radical values less than the literature predicted. The African-American newspaper in St. Louis found itself influencing the national and global agenda regarding Ferguson and the ongoing oppression of blacks in the city and surrounding municipalities. Mobile media savvy protestors broadcast police actions from the front lines of dissent in nearly constant live streams day after day from August to November, altering the scope of counternarrative and providing distilled counterpropaganda. In this study, researchers provide a snapshot of the alternativeladvocacy press as it rose to fill in gaps in coverage and to find untold stories in one of the most widely broadcast events of 2014 .

Keywords: Ferguson, alternative news media, advocacy press, qualitative method, normative theory, live streaming.

\footnotetext{
1 Contact with author: mpoepse@siue.edu.

2 Contact with author: cpainter1@udayton.edu.
} 


\section{Introduction}

Ferguson, Missouri, Police Officer Darren Wilson shot and killed 18-yearold Michael Brown August 9, 2014. Wilson initially stopped Brown and his friend, Dorian Johnson, for jaywalking, but Wilson also realized that the two young men matched the suspect description from an earlier strong-arm robbery. Brown, according to St. Louis County Police Chief Jon Belmar, physically assaulted Wilson through the window of Wilson's police vehicle and reached for Wilson's gun. After one shot was fired, Brown and Johnson fled, with Wilson pursuing. When Brown stopped and turned to face Wilson, the officer fired at Brown several times, killing him.

Protests, most peaceful but others violent, followed the shooting. The protesters argued that the shooting was racially motivated-Wilson is White, Brown was Black-and that Wilson shot an unarmed man trying to surrender, leading to chants of "Hands up, don't shoot." More protests followed the November 24 announcement that a St. Louis County grand jury decided not to indict Wilson. The U.S. Department of Justice cleared Wilson on civil rights violations March 4, 2015, although they did report a pattern of racial bias in arrests and fines by police in Ferguson and surrounding municipalities.

The purpose of this study is to explore the role of the alternative press in the coverage of the Wilson-Brown shooting and subsequent protests. Media often simultaneously perform various roles, some of which are complementary, others of which are contradictory. In this study, the term "alternative press" will be used to encompass the media ecology of a non-mainstream press, including alternative newsweeklies, ethnic media, and citizen journalists broadcasting primarily livestreaming video but also publishing via other media.

\section{Alt Press and Normative Theory}

The alternative press historically has been known by many names: partisan (Pasley, 2001), dissident (Ostertag, 2006; Streitmatter, 2001; Kessler, 1984), underground (McMillian, 2011; Lewes, 2000; Armstrong, 1981), alternative (McMillian, 2011; Atton \& Hamilton, 2008; Peck, 1998; Armstrong, 1981; McAuliffe, 1978), and online (McMillian, 2011; Streitmatter, 2001). A nonmainstream press system is neither time-bound nor period-bound but has existed alongside the mainstream press since the earliest days of the republic 
(Kessler, 1984). An alternative press surfaced throughout American history to service the informational and communication needs of social movements.

The characteristics of the alternative press differ depending on national context. Any press system exists within an overarching political, social, economic, and legal framework. In the United States, that press system has several distinctive features. One, there is a defined autonomy from the state (Hallin \& Mancini, 2004) based on legal and normative rules concerning issues such as free expression, access to information, privacy, and intellectual property (Starr, 2005). Two, commercial newspapers developed relatively early, marginalizing other forms of noncommercial media (Hallin \& Mancini, 2004; Baldasty, 1992). Three, there was an early expansion of literacy and primary education (Starr, 2005; Hallin \& Mancini, 2004), creating a public and potential audience. Fourth, journalistic professionalism is relatively strongly developed with a value system and standards of practice rooted in public service (Hallin \& Mancini, 2004). Members of the alternative press in the United States often describe themselves as serving the public better than those working in the mainstream.

The central role alternative media serve is providing a radical voice (Christians et al., 2009; Atton, 2002). Protest groups, radicals, and those on the fringes of society traditionally have been underserved or ignored by mainstream media (Kessler, 1984). The response of these groups has been to circumvent the mainstream press by starting their own newspapers, magazines, and Web sites (Streitmatter, 2001; Kessler, 1984). Alternative media seek to give voice to the voiceless (McMillian, 2011; Atton, 2002; Kessler, 1984; Armstrong, 1981), and to invert the power hierarchy of access by developing media spaces where activists and ordinary people can present accounts of their experiences and struggles (Atton, 2002). The alternative press recognizes and refutes mainstream media power centers, and as technologies change the mainstream press may become more capable (Couldry \& Curran, 2003). The ultimate goal of alternative media is the transformation of roles, responsibilities, ideals, and standards for journalism and society at large (Atton, 2002).

The alternative press typically is based on and compared to the mainstream press (Lewes, 2000). Several characteristics could be used when defining and then comparing the alternative and mainstream press systems. In this study, researchers will focus on six characteristics found in the literature: content or story selection, the use of objectivity, sourcing, tone, efforts at community building, and relationship to the mainstream media. 


\subsection{Content or story selection}

The search for and retransmission of certain kinds of news and information is a key component of any normative definition of journalism (Christians et al., 2009). However, the media's relationship to social, economic, and political power shapes their ability to perform the monitorial role adequately (Christians et al., 2009; Gans, 2005; Herman \& Chomsky, 2002; McChesney, 1999). New technologies give individuals the capability to monitor those in power, whether they hold elected office or wield media power (Keane, 2013). Taking the monitorial role to its logical limit, Keane (2009) suggests the future of democracy is built on this kind of monitoring where electing leaders is perhaps less important than monitoring and influencing them once they hold office. This type of monitoring is an extension of a role alternative media have claimed for decades.

Alternative press scholars have argued the mainstream press traditionally did not thoroughly or adequately fulfill its role to provide an outlet for people to express their views, especially if those people are non-elite, non-white, nonmale, or express dissident or radical viewpoints (McMillian, 2011; Atton, 2002; Kessler, 1984; Armstrong, 1981). These scholars argue that forms of dissident, underground, and alternative media have attempted to expand the public sphere by creating a two-way channel of communication between writers and audiences; by inverting the power structure by publishing the stories, opinions, and perspectives of non-elite sources; and by serving the bridging and bonding functions of establishing communities.

Alternative media serve the function of filling the gaps left by mainstream media (McMillian, 2011; Atton \& Hamilton, 2008; Armstrong, 1981; McAuliffe, 1978). News topics uncovered, under-covered, or mis-covered by the mainstream press are given space in alternative publications (McMillian, 2011; Ostertag, 2006; Streitmatter, 2001; Armstrong, 1981).

\subsection{An approach to objectivity}

Objectivity is the belief that one can and should separate facts from values (Schudson, 1978). The mainstream press adheres to standards of objectivity (Mindich, 1998; Schudson, 1978). The alternative press makes no claim that it is objective (Atton \& Hamilton, 2008; Lewes, 2000), and is by definition partisan (Atton, 2002). Partisanship here is not tied to a political party but instead is 
issue-oriented. One problem of the mainstream press, according to critics in the alternative press, is its adherence to objectivity (Lewes, 2000). It is impossible to separate facts from values, and morally and politically wrong to do so (Atton \& Hamilton, 2008). As Carpentier, puts it,

"one should keep in mind that information is not a neutral concept, and that it is epistemologically impossible to map out the exact boundaries between 'factual' information and the representations information contains. Factuality builds on representational regimes that are unavoidable in their presence, varied in their nature, and at the same time targeted by hegemonic projects. But it still remains possible to elaborate (factual) information characteristics which offer to strengthen the democratic quality of media output." (2009: 15)

Facts, when grouped together as "information" become even more value laden. But even if it were possible to separate facts from values, objective facts are not the same as the truth, and facts are less important than the truth (Lewes, 2000).

News, therefore, is not objective; instead, it is a selected account chosen for its ability to please both advertisers and readers (Baldasty, 1992). The constructed reality of the news is the result of a negotiation between journalists and other institutions, including sources, advertisers, political parties, government agencies, and readers (McChesney, 1999; Baldasty, 1992), and public relations firms.

\subsection{Sourcing}

One structural choice that goes hand-in-hand with objectivity is a reliance on authoritative sources (Mindich, 1998). Objectivity forces reporters and editors to rely on official sources, and this reliance propagates the status quo by leading journalists to seek official, authoritative power holders as primary sources of news and comment (Mindich, 1998). This reliance on official sources biases the news because it limits the number and variety of voices that are heard in the press system, and these sources might not always be credible.

Underground journalists relied almost exclusively on non-official sources (McMillian, 2011; Lewes, 2000). Part of the reason was that a reliance on official sources led to a news system that was framed or slanted against the coun- 
terculture and toward the mainstream middle (McMillian, 2011; Lewes, 2000). Reporters in the underground press wanted the voices of ordinary people to balance this perceived news slant (McMillian, 2011; Lewes, 2000).

\subsection{Tone}

Alternative publications use a hip, with-it tone-including the use of fourletter words, as well as sometimes-explicit references to sex, nudity, and drugs (McMillian, 2011; Peck, 1998; Armstrong, 1981). This cool, with-it tone also served as a way for underground journalists to differentiate themselves from the mainstream press. Tone became one marker of the radical perspective. Tone and content also were a way for underground journalists to construct a society by differentiating between an in-group (those who understood and accepted such language and visuals) and an out-group (everyone else).

\subsection{Efforts at community building}

Alternative media tend to be heavily community centered (McMillian, 2011; Christians et al., 2009; Armstrong, 1981). For the alternative press, community is forged through an alliance of the powerless, and the politically and culturally disenfranchised. Here, the radical role intersects with the collaborative and facilitative roles.

For a mainstream press, the collaborative role implies a partnership built on a mutual trust and shared commitment between the media and the state to mutually agreeable means and ends (Christians et al., 2009). Alternative media also perform a collaborative role. However, the alternative press collaborates by being a change agent instead of collaborating to maintain the status quo. The collaboration is between alternative journalists and their community instead of established, mainstream state and economic institutions.

In the facilitative role, the media seek to promote dialog among readers through communication that engages them and in which they actively participate (Christians et al., 2009). The media, in the facilitative role, promote communication that engages readers to participate actively (Christians et al., 2009). However, the facilitation provided by the mainstream press traditionally has spoken for and to the homogenous middle (Ostertag, 2006; McChesney, 1999; Kessler, 1984). There is little room for dissident viewpoints or radical critiques. 
Dissident groups, therefore, must create their own communications systems to construct an alternative reality if they want to share their ideas and ideals (Kessler, 1984). These groups seek two audiences with their media outlets. The first audience is internal, and the aim is to build a counterculture community of like-minded voices (Kessler, 1984). The second audience is external, and the aim is to convert more people to the cause by expanding the base of people hearing the protest message, to transmit the protest message of the dissident group on its own terms, and to provide a channel for a mainstream audience to communicate with the dissident group (Ostertag, 2006; Streitmatter, 2001; Kessler, 1984).

\subsection{Relationship to mainstream media}

Alternative media also serve as an oppositional voice to the mainstream media (Atton, 2002). Indeed, radical journalists assume the mainstream media are part of the power elite that the alternative press publications seek to subvert. Alternative media, therefore, watch the watchdog by monitoring traditional media outlets (Lewes, 2000). The watching the watchdog role arose out of the underground press, which sought a rebellion against both the national establishment and the mainstream media. That tradition continues today, with the alternative press providing needed context to news stories, providing differing frames and views, critiquing the mainstream press' coverage of certain issues, and poking fun at the mainstream press when it begins to take itself a little too seriously. The alternative press also serves a community as a second source of news (McMillian, 2011; Armstrong, 1981), assuming the role of the second paper in cities with only one daily newspaper.

\section{Method}

The researchers conducted nine semi-structured interviews between March 18-24, 2015-two with journalists (Chris King and Kenya Vaughn) at the St. Louis American, an African American weekly newspaper published continuously since 1928; four with journalists at the Riverfront Times (Jessica Lussenhop, Ray Downs, Danny Wicentowski, and Lindsay Toler), established in 1977 in St. Louis and sold in 1998 to what became, through merger, the Voice Media Group; and three with livestreaming broadcasters (Mustafa Hussein, Lee Mai- 
bes, and Bassem Masri), protestors who provided live video and micro-blogging coverage using lightweight cameras and/or mobile-phone cameras. Eight of these interviews were in-person; the interview with Mr. Masri was conducted via phone because he was not available to meet in person. Researchers used a semi-structured interview approach, which allowed them to strike a balance between gathering detailed, first-person accounts while still ensuring that the concepts organizing this study were addressed by each interviewee. The researchers explored the phenomenon by gaining a thick description from those who experienced it and could retell that experience in a comprehensive way (Creswell, 2006; Geertz, 1973).

Interviews are not neutral but are a negotiation between two or more people that result in a contextually based outcome (Fontana and Prokos, 2007; McCracken, 1988). Researchers let respondents tell their own stories, not strictly answer pre-planned questions (Berger, 1998; McCracken, 1988). Interviews were loosely structured around topics, not questions, such that each conversation started and ended wherever necessary to get the most rich, useful information. Conducting interviews also allowed the researchers to dig deeper by including more specificity over the course of long encounters (Fontana and Prokos, 2007; McCracken, 1988). Interviews lasted 45-75 minutes each.

\section{Findings}

The news organizations and citizen journalists studied here each provided alternative voices to mainstream news coverage, and to each other. Chris King described the St. Louis American, the oldest active alternative publication in the city, as a community and advocacy paper for the oppressed African-American community in St. Louis:

We don't really see ourselves as an alternative in the sense that it's used in our industry. The Riverfront Times is an alternative newspaper, and we're not in that sense, but we're certainly not a mainstream newspaper, so we're an alternative to the mainstream, but we're also, frankly, an alternative to the alternative media because a lot of alternative media covers, you know, they cover smut a lot, and they do a lot of crime reporting, and they're attention grabbing in many ways that we're mostly not. We have a huge newspaper-in-education section, and our newspaper is read in schools as 
part of that program, so we're conscious that our papers are picked up by school kids, so we are kind of a family publication in ways that very few newspapers are anymore.

Jessica Lussenhop, managing editor of The Riverfront Times, described her paper as being far less radical than historical alternative papers. The Riverfront Times, from her perspective, is not an advocate in the community; however, covering Ferguson put the paper in touch with its radical roots:

I've worked in this company for almost five years. Sort of the gospel was always that, "We don't want to do what you think a typical liberal alt-weekly would do. We don't want everyone saying this is just the liberal rag or whatever. We want to do stories that are objective and that take a surprising and interesting look at things and don't just sort of do the knee-jerk liberal story." And I've been hearing that from my bosses and sort of "corporate" for as long as I've worked here, and I agree with that to a certain extent. But it was interesting that as soon as all this stuff started happening, it seemed so obvious that there needed to be a slightly more liberal voice in local media here. The Post-Dispatch does a good job, I think, but people don't trust them for whatever reason, and there's just not a lot of other media, in print anyway, here, so it was interesting to sort of get back in touch with the sort of liberal roots through this whole Ferguson experience.

The most radical points of view were expressed on the front lines of the protest. With the advancement of affordable, mobile personal video broadcasting capabilities, protestors were able to document and livestream their activities and police actions during the protests. They documented their own sentiments, interviewed other protestors, and showed at times millions of online viewers what militarized police tactics look like from the protestors' viewpoint. Livestreaming broadcaster Mustafa Hussein considers himself a reporter first and a protestor second. He described his approach as "embedding" with protestors. Hussein and other volunteers had been working to resurrect the name of the African-American newspaper the St. Louis Argus and rebrand it as a radio station for independent music and left-wing political talk when Michael Brown was killed and the Ferguson protests began.

We had just purchased a bunch of livestreaming equipment for the purpose of doing concerts for independent artists, and we had actually purchased 
that on August 8, the day before Michael Brown was shot in Ferguson, and on the 13th, my wife and I were watching Fox 2 [local], flipping back and forth between CNN, KMOV [CBS local], trying to get a feel for what was going on in Ferguson, and in between the traditional standard program scheduling for a major news outlet like that you would only get bits and pieces and by the time the news clip or the b-roll of what was going on in the community, by the time that got through the producers and the editors and everything, you would get even less of a sense of what was going on in Ferguson, so I literally told my wife I'm going to take the livestreaming equipment and go out there.... The first night, I was livestreaming [August 13], the livestream went viral: 3.5 million viewers. I was actually in the bushes hiding from the St. Louis County Police as they were advancing through the neighborhood when Chris Hayes called from MSNBC.

Hussein created an alternative media source, or at least the potential for one, out of chance timing and consistent coverage of protests for close to three months after the Wilson-Brown shooting.

Hussein was not the only livestream broadcaster. The Argus News Radio Web site broadcast video from several livestreamers, including Hussein. Additionally, several independent livestreamers emerged from the protests to document their own experiences via video-streaming sites and Twitter. Each has the ability to display raw video online and to determine the course of coverage according to their agendas.

The rest of the findings are organized according to the six characteristics of alternative press found in the literature review. Comparisons between the African-American community advocacy paper, the alternative newsweekly, and the protestor-broadcasters are fascinating to consider as each had its own orientation to protestors, police, and the global public via mainstream media proxies and/or the Internet.

\subsection{Content or story selection}

Riverfront Times journalists described three overlapping periods of Ferguson coverage that influenced story selection. The first time period stretched from the August 9 shooting death of Michael Brown to August 12, when large numbers of national media arrived. The next period started August 13 and lasted 
about eight weeks, fueled to some degree by another police-involved shooting October 9. During this period, national and global mainstream news coverage was at its height. Journalists "parachuted" in to cover the protests and police crackdown, and the newspapers sought under-covered alternative stories. Between mid-October and the November 24 announcement that Wilson would not be indicted, the organizations were able to focus on weekly deadlines and the more sporadic "Ferguson October" protests (Ferguson Timeline, 2014).

Covering breaking news stretched the resources of The Riverfront Times, according to Lussenhop:

In the earliest days, the news coming out of Ferguson was 24 hours, so we just had to break [our reporting] down just by time of day.... I hate the phrase, but just "bearing witness," just feeling it was important to have someone out there, especially at night, to observe how the police were behaving.

Lussenhop said reporters Ray Downs and Danny Wicentowski covered protests together daily until 3 or 4 a.m., and it became difficult for them to craft independent narratives. Wicentowski covered looting August 10 by driving directly to a strip mall, but that kind of breaking-news coverage became unnecessary once the national news media arrived. Wicentowski said,

It was a stated aim to look for the stories the national media were not covering once the hordes appeared in Ferguson.... The mainstream was covering the stuff everybody knows.... We were always looking for something other than that.

With only four-to-five reporters and editors covering Ferguson, The Riverfront Times journalists reported stories with fringe appeal because mainstream media organizations began blanket coverage.

King described the St. Louis American content before, during, and after the height of the Ferguson protests as focusing on the community:

We emphasize positive news about the African-American community in the St. Louis region, so we'll cover a lot of things that a daily newspaper and an alternative newsweekly both would think is ridiculous, simple good-news stories, and we won't do them only on a slow news week. We don't actually think we have a front page unless we have something that's 
inspirational in some way, and that's partly because we're reporting about and to a community that's under siege and was under siege before everyone else noticed.

After the immediate breaking-news phase passed, St. Louis American Web Editor Kenya Vaughn walked from her home to the protests. She was a constant presence. "I covered the mundane protests.... I tried to show that most protests were peaceful." Reporting from the "body" of the crowd, Vaughn offered a perspective that advocated without agitating. "We're not blind advocates," she said.

Livestreamers' mere presence constantly documenting protests provided an alternative source of information for audiences. Their video feeds showed police action from the protestors' point of view, providing a counterpoint to the official narrative. Content often included interviews with protestors and documented hostile confrontations with police. Argus Radio featured stories on issues underlying the protests, such as an article about a man who was fired from a hotel in St. Louis for posting a picture of a Department of Homeland Security vehicle parked in the hotel parking lot. Hussein said,

The local channels did not want to touch it because Drury Inn is a St. Louis company, and we picked up the story.... We got some footage from the parking garage before the Department of Homeland Security had an opportunity to move their vehicles, which they promptly did after we published, and then CNN picked up that story from us, and it gained national attention.

Other livestreamers considered themselves protestors more than journalists. Lee Maibes accumulated more than 340,000 views during dozens of protests:

I realized that being behind the camera but also knowing the people allowed me to...narrate what was going on.... The biggest thing for me is like first-person coverage of the movement but trying to take myself out of it like explaining police tactics, trying to explain what demonstrators are doing and why they're doing it... and why the chants are being used.

Thus, livestreamers brought both issues and tactics to audiences around the globe. 


\subsection{Objectivity}

Demonstrating a measure of objectivity in reporting was more important for editors and reporters at The Riverfront Times than journalists at the St. Louis American. Livestreamers argued that they were documenting reality with their cameras but also readily acknowledged that where they direct the cameras could carry inherent bias.

St. Louis American editor Chris King does not believe that any news organization is objective:

People need information, and they need people to give it to them, and I think they should be provided the information as plainly and as transparently as possible - disclosing your motive and your agenda as a mediumand everyone has an agenda, especially the ones that act like they don't.

Livestream broadcasters said that their raw-video streams presented a measure of objectivity, but they recognized their efforts were to demonstrate police actions and abuses. Lee Maibes said,

I think it shows reality as it is, but pure objectivity, no. People need to be honest about this, about being a livestreamer. You're embedded with the crowd almost 100 percent of the time. You're not going to film people doing things that could get them in trouble. Your job is to be very careful about those things. It's more to shine a light on police and police behavior because I don't think traditional journalism or mainstream media is being objective either. That's the thing really. That's why I say it's counternarrative.

Similarly, Bassem Masri said, "When I'm out there, and I'm streaming, I don't tell people the truth. I let them watch it for themselves. So you can say that it's objective in a way, but I give them an angle that most of them can't get."

Perhaps most surprisingly is the level of objectivity sought by Lussenhop, The Riverfront Times managing editor: "We want objective, surprising, interesting stories." The corporate culture of Voice Media Group could be influencing the attitude of the newspaper, according to Lussenhop, and the directive is to not be predictably liberal. Lussenhop said she reined in Reporter Ray Downs at times when he became argumentative in his copy. Downs said he had reasons for eschewing the objectivity norm: 
People think that you have to have both sides of the story. "This person says this, and that person says that." That's one way of doing it, but, in this case, you had these people that are angry about the police; the police are not making any statements about it, about what people think about police brutality, so it's kind of hard to get the other side of that story. So, the story is obviously there's some kind of tension here...Here's what these people think about it.

When Wicentowski covered radical actors, he said: "I was trying to be objective and to evaluate, but also to objectively reflect just how shitty this situation was and that the system itself was a failure and that it was already rotten and that it was objective to paint it as that."

There is a decided aversion to sensationalism in the St. Louis American that allows for balance in the organization's orientation to officials without forcing anyone to adhere to the objectivity norm in reportage. St. Louis American staffers invited St. Louis City and County police leaders to its offices to meet with editorial staff before the Wilson grand jury decision. King said,

So-called objectivity often distracts from the truth. If one person says something that has a lot of credibility, and you just call the other side for them to deny it, and you give them equal space, one side has a lot of credibility, and the other side is simply denying it because the truth hurts them.... We are always making judgments on what is true by how we present information. I think all we can do is be transparent about where did we get our information, how can we substantiate it, and how does it compare against other things that we know to be true?

\subsection{Sourcing}

Livestreamers primarily used fellow protestors as sources but occasionally got responses from police. The Riverfront Times was limited to protestor and witness testimony in many cases, though its reporters attempted to get official sources. St. Louis American journalists stuck with the same key sources they had relied upon for years.

Police departments strictly forbade officers from talking to media outlets. Livestreaming protestors such as Bassem Masri, however, would instigate contact with police and try to elicit a response. He also would interview protestors 
about their experiences with police. Lee Maibes described "sourcing" police in her livestream broadcasts as a way to keep tabs on them and to try to protect protestors:

Police are a lot less likely to act when there's a livestreamer present. Well, it depends, but the last time I was out...the commander was like, "Are you going home?" I'm like, "Are you going to pick people off when I leave?" He's like, "You're not going home then." I'm like, "Are you going to arrest people?" And he was like, "No." And I was like, "I think you're full of shit, but I'm going home anyway." So on my way home, I catch him pulling people over and harassing them. So it's basically to try to keep people safer, to show the reality of confrontation with police.

Riverfront Times' Lussenhop invited commentary, even anonymous commentary, from police officers whom she previously had interviewed. She said one officer toyed with the idea:

He's a nice guy...it seems like he's not racist as far as I could tell, so I thought it would be great to have a cop, just any cop. Just give us your perspective anonymously that we could say, "Here's someone that's been patrolling Ferguson; here's what it's like for them." And he wouldn't do that. I wanted to get a sense of what it was like-like will you have lunch with me off the record to chat, and he was like, "Sure, that's fine." And he said, five minutes later, "I just talked to my supervisor, I can't." I was like, "Even to chat?" And he was like, "I can't."

All of The Riverfront Times journalists described their efforts to contact police only to be rejected and left with nothing or with a press release including a stock quote. Wicentowski said his reporting often looked imbalanced not because he was disinterested in the police point of view but because police refused to be interviewed. Lussenhop said she eventually gave up contacting police sources because it became a waste of time contacting individuals and departments she knew were not responsive.

St. Louis American reporters had the sources everyone else wanted. Editor Chris King asked for commentary from key contributors before media hordes arrived knowing that the newspaper's key sources would be spending a lot of time being interviewed for cable TV news and for national newspapers and magazines. King noted that his number got passed around national media 
outlets, and he was frequently the first call reporters made when they arrived in town:

I can't tell you how many people I saw on CNN before I saw in the PostDispatch who we'd covered for years, and the Post used to really have very poor sources in the black community. The Post-Dispatch really benefited from Ferguson because now they actually know the influential AfricanAmericans in the community.

St. Louis American reporters assumed news consumers received the official police account from local television or from the Post-Dispatch, so they generally sourced their articles to tell stories from a different perspective.

\subsection{Tone}

Live broadcasters, as frontline activists, often struck an aggressive tone while narrating livestreams, but there was variation based on the individual behind the camera. At The Riverfront Times, individual reporters determined tone, although editors checked Ray Downs' more argumentative approach. St. Louis American reporters were quite restrained, skeptical but not incendiary. St. Louis American Web Editor Kenya Vaughn lives near Ferguson. She walked to protests without credentials and covered dozens of protests for daily online deadlines. She described her tone as trying to be the voice of reason despite how the police activity affected her:

I was driving home on Wednesday (August 13) because I have to drive through Ferguson to get anywhere I'm going to go. They had West Florrissant blocked off, so I had to go through a back street, and I saw this girl holding a baby. It was her little sister. She said, "We can't get home. Police have our car blocked in.... We came to protest, now we're ready to go." So I asked, "Did you ask police to move the car? Would you like me to ask?"

So I said, "Excuse me, officer." They pointed their guns at my chest.... They never drew down. They said they were going to have to wait until the morning to move their car, so I gave them a ride home. So that was how I was introduced to what was going on, the relationship between the police and the protestors.... I tried to make sure that I didn't let that feeling permeate through my stories, that I didn't go too hard, anti-police.... I mean 
if this is your first experience with unjust policing, then of course you're going to be angry. I mean, I've had 30 years to let it settle in.

Global media outlets were reporting issues the St. Louis American had covered for decades. Behind the scenes, Chris King was talking to police and protest organizers to keep violent elements out. Vaughn covered the "mundane" protests in straightforward tones. "My stories were more chill, more human because I felt like the core of what the protests were for, like they were getting lost in that, so my goal was that the people responsible for Ferguson unrest existing still had a voice."

Bassem Masri is well known for being one the most radical, outspoken protestors. Of Palestinian descent, he lived for a time in Jerusalem. St. Louis now is his home. He was featured on national cable television outlets shouting at a police officer that he "spits on police" and speaking in heated language day in and day out at protests. During the protests, he reached a total of 1.5 million views. Masri said,

My tone was very angry, very passionate, you can say, you know a lot of conviction basically because it's not something fabricated. It's very genuine. That's why people are attracted to that stream. It's because I'm telling the truth, and I'm saying it in a way that can't be written down and preplanned.

In his livestream broadcasts, Mustafa Hussein set a less incendiary, protestpositive tone. Protest organizers communicated directly with him to let him know beforehand when and where they would be staging demonstrations outside of Ferguson, and he would provide live coverage with an effort not to sensationalize. Hussein said,

I think one thing that we discovered really quickly is there's no such thing as true, unbiased coverage of anything, even without any narrative or any vocal prompting on the livestream from behind the camera, what you point your camera at dictates the tone. Two people can be livestreaming the same event. If you're camera is pointed at police, the tone of your livestream is set by the ideal that you're looking to catch the police do something wrong. If your camera is pointed constantly at the protestors, then the tone of your livestream is we're going to catch them looting in this building, or we're going to catch them doing something wrong. 
Hussein conflates tone and truth strategy because of the way livestreaming functions. Constant, live broadcasts carry implied tones for audiences, and livestreamers quickly learn how to manipulate that for effect. It is vernacular video countering the surveillance state with its own surveillance. Livestreamers have an in-group including thousands of Twitter, YouTube, and Ustream followers.

Reporters at The Riverfront Times, the only media source in this study that self identifies as an alternative newsweekly, described their tone as "vanilla, passionless" (Jessica Lussenhop), "not trying to shame officials" (Lindsay Toler), and "really resistant to trying to make points or trying to build to some kind of, you know, message” (Danny Wicentowski). Ray Downs' tone was critical:

You know, I've always been interested in police militarization and police heavy-handedness in how they deal with certain things, and the fact that they brought out the MRAPs and SWAT teams and all of that on the first night before anything happened with the protestors was fascinating, so I kind of jumped on that angle and covered just the protests for the first couple of weeks.

However, as stated previously, Downs' editors told him to tone down his articles. The attitude of Riverfront Times journalists was that the situation was as radical as it gets in St. Louis and that covering it without taking the police perspective essentially would prove to be hip enough. This attitude was not the same as jazzing up a restaurant review or posting a slideshow of a burlesque show. The event was both radical and reactionary. Covering it without taking police press releases to heart and without inciting riots was the primary goal.

\subsection{Community Building}

The journalists interviewed from The Riverfront Times stated that community building was not their intent. They made it clear their publication is not an advocacy paper. For the St. Louis American, community building is the mission, and the Ferguson protests provided an opportunity to demonstrate their ongoing efforts to build community by demanding positive attention and change. Protest violence, early rioting, and the police crackdown generated lasting images in the national psyche, but the real result of Ferguson might be changed municipal policing practices or the collapsing of several municipalities 
into one dominated by suburban African-Americans. Toward that end and in support of local leaders, the paper did its job. Livestreamers were demonstrating new tools and techniques for online organization. The role Twitter played in the Arab Spring uprising has been well documented. Now such protests have a videotrack used to unite home viewers with activists and citizen protestors. The concern among livestreamers is that the federal government always is preparing to fight a mass uprising in many cities as though it were a civil war and that the militarization of police is not understood for what it is - a sort of second National Guard loosely organized in the hands of municipalities with varying levels of oversight and varying concepts of what "proper use of force" means. The community being built in Ferguson was one of hundreds, at times thousands, of local protestors with exponentially more people watching at home. That said, more people saw the sources the St. Louis American provided to the national media than any of the livestreams at the height of the protests.

\subsection{Relationship to mainstream media}

By pointing cameras at police, livestreamers argue they were bringing balance to coverage because mainstream outlets carried the official version of events while livestream viewers had a forced perspective: They had no choice but to see the protest through activist eyes.

Livestream broadcasters did see their video co-opted by mainstream news organizations in ways that brought the protestors' point of view into viewers' living rooms, although, according to the three livestream broadcasters interviewed for this study, their video often would appear without attribution and would be divorced from much of the context they were trying to provide. They were offering a counter-narrative filtered to suit the protestors' purposes to countervail what they often saw as blind, "press release journalism" on the part of the local major metro daily, the cable networks, and some national newspapers.

Perhaps the most nuanced relationship was the one the St. Louis American had with the St. Louis Post-Dispatch and parachute journalists from national newspapers and networks. Many national political reporters followed Chris King on Twitter as it became clear that Ferguson was a national story and that he had contacts in the city. King spoke of meeting for beers with reporters as they landed in town and of giving phone numbers and feeding leads to reporters because his mission was to get the St. Louis American's stories out to a wider 
audience, not to grow the paper or generate fame for himself. At the same time, he was competing with the St. Louis Post-Dispatch on how to frame issues and whom to interview, and the continued community-building work in St. Louis falls more squarely on the shoulders of the community advocacy paper than on anyone else studied here.

\section{Conclusions}

The purpose of this study was to explore the role of the alternative press while covering the Darren Wilson-Michael Brown shooting and subsequent protests beginning August 9, 2014. The researchers conducted nine in-depth interviews with journalists from The Riverfront Times, the St. Louis American, and livestreaming broadcasters. In these interviews, researchers focused on six characteristics of the alternative press found in the literature: content or story selection, the use of objectivity, sourcing, tone, efforts at community building, and the relationship to mainstream media.

Each of the three types of media performed the radical role. One major component of the alternative press is to provide a voice to the otherwise voiceless (McMillian, 2011; Atton, 2002; Kessler, 1984; Armstrong, 1981). Livestreamers, some of whom considered themselves protestors rather than journalists, showed police action from protestors' point of view, providing a necessary counterpoint to the official narrative. Similarly, St. Louis American reporters generally sourced their articles from a non-official perspective because they assumed the mainstream press provided the official police account.

In such coverage, these news outlets also sought to monitor traditional media (Lewes, 2000) by providing a second source of news (McMillian, 2011; Armstrong, 1981). This coverage was part of both the radical and monitorial role. The Riverfront Times sought uncovered or under-covered stories, especially after the arrival of the national media. St. Louis American journalists, however, had a nuanced relationship with the mainstream press, readily sharing sources and ideas with the daily St. Louis Post-Dispatch and national print and broadcast media. Chris King considers the St. Louis American a community paper, alternative to the mainstream but also to traditional alternative media, and he sought to extend his newspaper's message in any way possible.

Filing the gaps left by mainstream media also is part of the monitorial role of the alternative press (McMillian, 2011; Atton \& Hamilton, 2008; Arm- 
strong, 1981; McAuliffe, 1978). The monitorial role, or the search for and retransmission of certain kinds of news and information, is a key component of any normative definition of journalism (Christians et al., 2009). Riverfront Times journalists sought to balance coverage because mainstream media outlets carried the official version of events. In the St. Louis American, journalists emphasized positive news about the African-American community, which they described as being "under siege before everyone else noticed."

In the facilitative role, media seek to promote dialog among readers through communication that engages them and in which they actively participate (Christians et al., 2009). Alternative press journalists were uneven in promoting that dialog, though not because of a lack of effort. Livestreamers primarily sourced to fellow protestors but occasionally received responses from police, generally following provocation. Riverfront Times reporters sought dialog and balance, but their stories typically were one sided because police departments strictly forbade officers from talking to the press. St. Louis American journalists were the most successful at fulfilling the facilitative role by relying on official, nonofficial, and community sources developed long before Ferguson became a national story.

Alternative media tend to be heavily community centered (McMillian, 2011; Christians et al., 2009; Armstrong, 1981) and seek collaboration between alternative journalists and their community, not collaboration with state and economic institutions. Community building is the stated intention of the St. Louis American; its reporters seek positive attention and change. To that end, editor Chris King spoke with police and protest organizers to keep violent elements out of Ferguson. For livestreamers, the community is global, so they demonstrated new tools and techniques for online organization. Riverfront Times journalists do not consider themselves an advocacy paper, so they attempted to stick to hard news instead of trying to build community.

Traditional normative theory focuses on the radical role of the alternative press, but this focus will not suffice as a means of describing these organizations and individuals in the so-called Digital Age. Alternative media can inhabit many roles. In this study, we show examples of alternative publications, websites, and activists serving radical, monitorial, collaborative, and facilitative roles, sometimes simultaneously. Technological advancements and the abandonment of radical roles by some of the more well-established alternative publications have 
afford the opportunity for new actors to assume these roles and to act as a check on mainstream publications and broadcasters, but we cannot say with certainty whether or how the live streamers and web publishers will continue to operate. All we can add in terms of theory is the imperative that scholars must continue to monitor and describe the many normative roles these myriad rising publications and individual activists with dedication and data plans can fulfill.

Let us revisit the premise of this piece and offer a broader take on how this study relates to literature on monitory democracy (Keane, 2013). Keane (2013) explicates how institutions who monitor democratic society and its actions can serve "minoritarian' democracy" (p. 85). What the researchers have shown in this study is some evidence that the nature of representation is changing in relation to technological affordances. It is one thing for a monitoring institution to print and distribute free papers offering a radical point of view to urban dwellers who are fed up with the American mainstream press. It is another to establish beachheads in online and mobile spaces for real-time livestreamed media commentary. The livestreamers share similarities with the institutional alternative press, but they extend the capabilities and functions to the individual. Keane (2013: 85-86) established the concept: "where the old rule of 'one person, one vote, one representative' - the central demand in the struggle for representative democracy - is replaced with the new principle of monitory democracy: 'one person, many interests, many voices, multiple votes, multiple representatives'."

The individual livestreamer represent her or his views and those of dedicated audiences. Using their "second screens," viewers could watch mainstream media on cable television and simultaneously hear the radical point of view online on their laptops or mobile devices. Not only could they see and hear a radical point of view, they had several choices, multiple cameras all coming from heads in the crowd of protestors. It is significant that technology affords those with radical voices a way to illustrate their experiences using live video, which, although it is not unassailable, is difficult to refute. Livestreaming can be an individual act. Livestreamers can have and be one of the many representatives Keane (2013) speaks of.

The three livestreaming protestor/broadcasters interviewed here had different relationships with protest organizers and viewed themselves with varying degrees of opposition to police forces. What unified them was a feeling they could serve deeper truths by livestreaming what they and other protesters were 
doing and how they were treated by police throughout the days and nights of action. One livestreamer was attempting to start a media business. Another was more closely aligned with protest organizers and wanted to demonstrate the essential messages of protestors. The third might be classified as an independent radical taking his personal concerns about police profiling in St. Louis, where he lives, to the epicenter of the Ferguson protests. That the public can hear about these versions of the truth does not mean that they will, but this kind of monitoring is immediate, constant, and independent to the point that individuals can comment on mainstream agendas, affect them, and create new ones. Thus, this study bears witness to an important moment for minoritarian democracy as it arises through the establishment of monitory regimes. The new monitors build on norms established by existing monitorial institutions in the established alternative press and carry out many of the same functions, but they also represent a new capability, perhaps a responsibility, for individuals who challenge power.

One limitation of this study is that the researchers did not interview mainstream media professionals to analyze in what ways they applied professional norms in their coverage of Ferguson. We decided not to take this approach because it would have softened the focus of the work. While we do address relationships between media outlets here; they are dealt with from the alternative media point of view. This frame delimits our study and allows for a depth of analysis that would not otherwise be possible. Indeed, even within our limited scope, we found complex relationships between norms in organizations and between the norms organizations followed and those livestreamers were working to establish. The subject of alternative media coverage of socially contentious events deserves as much time and attention as we can spare given the importance of the alternative press, the potential of monitorial democracy and the dearth of theoretical work. 


\section{References}

Armstrong, D. (1981). A Trumpet to Arms: Alternative Media in America. Boston: South End Press.

Atton, C. (2002). News Cultures and New Social Movements: Radical Journalism and the Mainstream Media. Journalism Studies, 3(4): 491-505.

Atton, C. \& Hamilton, J.F. (2008). Alternative Journalism. Thousand Oaks, Ca.: Sage Publications.

Baldasty, G. J. (1992). The Commercialization of News in the Nineteenth Century. Madison, Wi.: University of Wisconsin Press.

Berger, A. A. (1998). Media Research Techniques. Thousand Oaks, Ca.: Sage Publications.

Carpentier, N. (2009). Developing Democratic and Negotiated Quality: Rearticulating Discourses of Quality Through Democratic and Participatory Media Practices. CM: Časopis za upravljanje komuniciranjem : Communication Management Quarterly, 13: 5-41.

Christians, C. G., Glasser, T. L., McQuail, D., Nordenstreng, K. \& White, R. A. (2009). Normative Theories of the Media: Journalism in Democratic Societies. Urbana, Il.: University of Illinois Press.

Couldry, N. \& Curran, J. (eds.). (2003) Contesting Media Power: Alternative Media in a Networked World. Lanham, Md.: Rowman \& Littlefield.

Creswell, J. (2006). Qualitative Inquiry and Research Design: Choosing Among Five Approaches. Thousand Oaks, Ca.: Sage Publications.

Ferguson Timeline. (2014, December 28). The St. Louis Post-Dispatch. Retrieved from http://www.stltoday.com/news/local/metro/ferguson-timeline/ article_c8c088c5-1bad-5d51-a0a6-e14a36ebc72f.html.

Fontana, A. \& Prokos, A. H. (2007). The Interview: From Formal to Postmodern. Walnut Creek, Ca.: Left Coast Press.

Gans, H. (2005). Deciding What's News: A Study of CBS Evening News, NBC Nightly News, Newsweek, and Time. Chicago: Northwestern University Press.

Geertz, C. (1973). The Interpretation of Cultures. New York: Basic Books.

Hallin, D. C. \& Mancini, P. (2004). Comparing Media Systems: Three Models of Media and Politics. Cambridge: Cambridge University Press. 
Herman, E. S. \& Chomsky, N. (2002). Manufacturing Consent: The Political Economy of the Mass Media. New York: Pantheon.

Keane, J. (2009). The Life and Death of Democracy. London: Simon \& Schuster.

Keane, J. (2013). Democracy and Media Decadence. Cambridge: Cambridge University Press.

Kessler, L. (1984). The Dissident Press: Alternative Journalism in American History. Beverly Hills, Ca.: Sage Publications.

Lewes, J. (2000). The Underground Press in America (1964-1968): Outlining an Alternative, the Envisioning of an Underground. Journal of Communication Inquiry, 24(4): 379-400.

McAuliffe, K. (1978). The Great American Newspaper. New York: Charles Scribner's Sons.

McChesney, R. W. (1999). Rich Media, Poor Democracy: Communication Politics in Dubious Times. Champaign, Il.: University of Illinois Press.

McCracken, G. D. (1988). The Long Interview. Thousand Oaks, Ca.: Sage Publications.

McMillian, J. C. (2011). Smoking Typewriters: The Sixties Underground Press and the Rise of Alternative Media in America. Oxford: Oxford University Press.

Mindich, D. T. Z. (1998). Just the Facts: How 'Objectivity' Came to Define American Journalism. New York: New York University Press.

Ostertag, B. (2006). People's Movements, People's Press: The Journalism of Social Justice Movements. Boston: Beacon Press.

Pasley, J. L. (2001). 'The Tyranny of Printers': Newspaper Politics in the Early American Republic. Charlottesville, Va.: University of Virginia Press.

Peck, A. (1998). From underground to alternative: Peace signs and dollar signs (Journalism in 1968 and 1998). Media Studies Journal, 12(3): 156-162.

Schudson, M. (1978). Discovering the News: A Social History of American Newspapers. New York: Basic Books.

Starr, P. (2004). The Creation of the Media: Political Origins of Modern Communications. New York: Basic Books.

Streitmatter, R. (2001). Voices of Revolution: The Dissident Press in America. New York: Columbia University Press. 
Alternative media and normative theory:

Mark Anthony Poepsel, Chad Painter

A case of Ferguson, Missouri 